\title{
Nocardiopsis potens sp. nov., isolated from household waste
}

\author{
Correspondence \\ A. F. Yassin \\ yassin@mibi03.meb.uni-bonn.de
}

\author{
A. F. Yassin, ${ }^{1}$ C. Spröer, ${ }^{2}$ H. Hupfer, ${ }^{3}$ C. Siering ${ }^{3}$ and H.-P. Klenk ${ }^{2}$ \\ ${ }^{1}$ Institut für Medizinische Mikrobiologie und Immunologie der Universität Bonn, D-53127 Bonn, \\ Germany \\ ${ }^{2} \mathrm{DSMZ}$ - Deutsche Sammlung von Mikroorganismen und Zellkulturen GmbH, Inhoffenstrasse 7b, \\ D-38124 Braunschweig, Germany \\ ${ }^{3}$ Kekulé-Institut für Organische Chemie und Biochemie der Universität Bonn, D-53121 Bonn, \\ Germany
}

\begin{abstract}
The taxonomic position of an actinomycete, designated strain IMMIB L- $21^{\top}$, was determined using a polyphasic taxonomic approach. The organism, which had phenotypic properties consistent with its classification in the genus Nocardiopsis, formed a distinct clade in the 16S rRNA gene sequence tree together with the type strain of Nocardiopsis composta, but was readily distinguished from this species using DNA-DNA relatedness and phenotypic data. The genotypic and phenotypic data show that the organism represents a novel species of the genus Nocardiopsis, for which the name Nocardiopsis potens sp. nov. is proposed. The type strain is IMMIB L- $21^{\top}\left(=\right.$ DSM $45234^{\top}=$ CCUG $\left.56587^{\top}\right)$.
\end{abstract}

The genus Nocardiopsis was proposed by Meyer (1976) on the basis of chemotaxonomic and morphological characteristics. At the time of writing, the taxon encompasses 28 recognized species and 4 subspecies, which form a distinct clade within the evolutionary radiation occupied by members of the family Nocardiopsaceae (Rainey et al., 1996). Nocardiopsis strains are frequently isolated from saline soils (Yassin et al., 1993a; Li et al., 2004, 2006), but they have also been recovered from an alkaline slag dump (Schippers et al., 2002), indoor environments (Peltola et al., 2001), the atmosphere of a composting facility (Kämpfer et al., 2002) and clinical material (Bernatchez \& Lebreux, 1991; Yassin et al., 1997). In the present polyphasic study, an actinomycete isolated from household waste was shown to represent a novel species of the genus Nocardiopsis.

Strain IMMIB L-21 ${ }^{\mathrm{T}}$ was isolated from a household dustbin on Brain Heart Infusion (BHI; BD) agar, glucose-yeast extract-malt extract agar (GYM; medium 65; DSMZ) and Columbia agar (BD) supplemented with $5 \%$ sheep blood. The organism was grown on yeast extract-malt extract agar (ISP 2), oatmeal agar (ISP 3) and inorganic salts-starch agar (ISP 4) as described by Shirling \& Gottlieb (1966) and examined for pigmentation and colour of aerial and substrate mycelia. Gram and ZiehlNeelsen stains were applied to hyphae grown on Columbia agar. Growth at different temperatures was determined at $10,20,27,37$ and $42{ }^{\circ} \mathrm{C}$ and a range of phenotypic characteristics was examined using standard procedures

The GenBank/EMBL/DDBJ accession number for the 16S rRNA gene sequence of strain IMMIB L-2 $1^{\top}$ is FM253114.
(Gordon, 1966, 1967; Gordon \& Mihm, 1957; Yassin et al., 1995). Tolerance to $\mathrm{NaCl}(0-16 \%)$ was tested in GYM broth. Biomass for chemotaxonomic studies was derived from a 7-day-old BHI broth shake culture incubated at $37{ }^{\circ} \mathrm{C}$, harvested by centrifugation and washed with distilled water. Standard procedures were used to determine the isomeric form of diaminopimelic acid (Becker et al., 1964), whole-cell sugars (Lechevalier, 1968), nonhydroxylated fatty acids (Minnikin et al., 1980; Yassin et al., 2007), polar lipids (Yassin et al., 1993b) and isoprenoid quinones (Collins et al., 1977; Yassin \& Hupfer, 2006).

Genomic DNA extraction and PCR-mediated amplification of the 16S rRNA gene sequence were carried out using established procedures (Rainey et al., 1996). The purified PCR products were sequenced using a Taq DyeDeoxy Terminator Cycle Sequencing kit (Applied Biosystems, Germany) following the manufacturer's protocol. An ABI 310 Genetic Analyzer (Applied Biosystems) was used for electrophoresis of the sequence-reaction products. The $16 \mathrm{~S}$ rRNA gene sequences of strain IMMIB L- $21^{\mathrm{T}}$ and those of recognized species of the genus Nocardiopsis, retrieved from GenBank, were added to the ARB database (Ludwig et al., 2004) and aligned using the respective tool from the ARB package. The resulting alignment was corrected manually and evolutionary trees were inferred using maximum-parsimony (Fitch, 1971), neighbour-joining (Saitou \& Nei, 1987) and maximum-likelihood (Felsenstein, 1981) methods. The evolutionary distance matrix for the neighbour-joining method was calculated using the correction of Jukes \& Cantor (1969). The 
topologies of the neighbour-joining tree were evaluated using bootstrap analyses (Felsenstein, 1985) based on 500 resamplings.

DNA-DNA relatedness studies were performed between strain IMMIB L-21 ${ }^{\mathrm{T}}$, Nocardiopsis composta DSM $44551^{\mathrm{T}}$ and Nocardiopsis halophila DSM $44494^{\mathrm{T}}$. DNA was isolated using a French pressure cell (Thermo Spectronic) and was purified by chromatography on hydroxyapatite as described by Cashion et al. (1977). DNA-DNA hybridization was carried out as described by De Ley et al. (1970) with consideration of the modifications described by Huß et al. (1983) using a model Cary 100 Bio UV/VISspectrophotometer equipped with a Peltier-thermostatted $6 \times 6$ multicell changer and a temperature controller with an in situ temperature probe (Varian).

Strain IMMIB L-2 $1^{\mathrm{T}}$ grew well on ISP $2-4$, producing a paleyellow to brown-yellow substrate mycelium that carried white aerial hyphae; diffusible pigments were not produced. Melanoid pigments were not produced on ISP 6 or ISP 7. The substrate hyphae fragmented into coccoid-to-rodshaped elements. The aerial hyphae bore chains of spores. The spores were elongated and had smooth surfaces. The hyphae were Gram-positive and non-acid-alcohol-fast. The organism grew at temperatures up to $37{ }^{\circ} \mathrm{C}$ but not at 10 or $42^{\circ} \mathrm{C}$. The range of phenotypic characteristics are listed in Table 1 and the species description.

Chemotaxonomic studies revealed that strain IMMIB L$21^{\mathrm{T}}$ had a chemical profile consistent with its assignment to the genus Nocardiopsis. The strain was characterized by the presence of meso-diaminopimelic acid with no characteristic sugars in whole-organism hydrolysates (cell-wall chemotype III according to Lechevalier \& Lechevalier, 1970). The respiratory quinones consisted of dihydrogenated, tetrahydrogenated, hexahydrogenated and octahydrogenated menaquinones with 9,10 and 11 isoprene units [MK-11 $\left(\mathrm{H}_{2,4,6,8}\right)$, MK-10 $\left(\mathrm{H}_{2,4,6,8}\right)$ and MK-9 $\left.\left(\mathrm{H}_{2,4,6,8}\right)\right]$ as the predominant menaquinones. The major phospholipids of strain IMMIB L-2 $1^{\mathrm{T}}$ were phosphatidylcholine, phosphatidylmethylethanolamine, diphosphatidylglycerol, phosphatidylglycerol, phosphatidylinositol and phosphatidylinositol mannosides (phospholipid type III according to Lechevalier et al., 1977). The fatty acid profile was dominated by iso- and anteiso-branched and 10-methylbranched fatty acids. Traces of straight chain unsaturated fatty acids were detected. The principal components were anteiso- $\mathrm{C}_{13: 0}(0.85 \%$ of total fatty acids $)$, iso- $\mathrm{C}_{14: 0}$ $(3.91 \%), \mathrm{C}_{14: 0}(2.71 \%)$, iso- $\mathrm{C}_{15: 0}(5.34 \%)$, anteiso$\mathrm{C}_{15: 0}(18.82 \%), \mathrm{C}_{15: 0}(3.05 \%)$, iso- $\mathrm{C}_{16: 0}(9.97 \%)$, $\mathrm{C}_{16: 1} \omega 7 c(1.04 \%), \mathrm{C}_{18: 1} \omega 9 c(3.16 \%), \mathrm{C}_{16: 0}(9.90 \%), 10-$ methyl $\mathrm{C}_{16: 0}(0.59 \%)$, iso- $\mathrm{C}_{17: 0}(2.99 \%)$, anteiso- $\mathrm{C}_{17: 0}$ $(11.16 \%), \mathrm{C}_{17: 1} \omega 8 c(5.90 \%), \mathrm{C}_{18: 0}(5.66 \%)$ and 10 methyl $\mathrm{C}_{18: 0}(4.53 \%)$. All of these chemical properties are consistent with the classification of the isolate in the genus Nocardiopsis.

To establish the phylogenetic position of strain IMMIB L$21^{\mathrm{T}}$, its $16 \mathrm{~S}$ rRNA gene sequence was determined in this
Table 1. Differential phenotypic characteristics of strain IMMIB L-21 ${ }^{\top}, N$. composta and N. halophila

Strains: 1, IMMIB L- $21^{\mathrm{T}}$ (Nocardiopsis potens sp. nov.; data from this study); 2, N. composta DSM $44551^{\mathrm{T}}$ (this study); 3, N. halophila DSM $44494^{\mathrm{T}}$ (this study). All strains were positive for hydrolysis of aesculin, casein, hypoxanthine and urea, utilization of L-arabinose, cellobiose, citrate, L-lactate and D-mannitol as carbon sources and utilization of L-alanine, gelatin, L-proline, L-serine and L-ornithine as simultaneous sources of carbon and nitrogen. All strains were negative for hydrolysis of adenine and utilization of $m$-hydroxybenzoate, raffinose, D-sorbitol and D-xylose as carbon sources. +, Positive; -, negative; w, weak utilization after 3 weeks.

\begin{tabular}{|c|c|c|c|}
\hline Characteristic & 1 & 2 & 3 \\
\hline \multicolumn{4}{|l|}{ Hydrolysis of: } \\
\hline Elastin & + & - & - \\
\hline Gelatin & - & + & - \\
\hline Guanine & + & + & - \\
\hline Testosterone & + & + & - \\
\hline L-Tyrosine & + & + & - \\
\hline Xanthine & - & + & - \\
\hline \multicolumn{4}{|c|}{ Sources of carbon and energy } \\
\hline Acetate & + & + & - \\
\hline Adonitol & + & + & - \\
\hline Adipic acid & + & - & - \\
\hline iso-Amyl alcohol & + & + & - \\
\hline 2,3-Butanediol & + & - & - \\
\hline meso-Erythritol & + & + & - \\
\hline D-Galactose & + & + & - \\
\hline D-Glucose & + & + & - \\
\hline D-Gluconate & + & + & w \\
\hline$p$-Hydroxybenzoate & - & - & + \\
\hline myo-Inositol & + & + & - \\
\hline Lactose & + & + & - \\
\hline Maltose & + & + & - \\
\hline Melezitose & + & - & - \\
\hline 1,2-Propanediol & - & + & + \\
\hline L-Rhamnose & - & + & - \\
\hline Sucrose & + & + & - \\
\hline Trehalose & + & + & - \\
\hline \multicolumn{4}{|c|}{ Sources of carbon and nitrogen } \\
\hline Acetamide & - & + & + \\
\hline
\end{tabular}

study (1498 nt). Sequence database searches revealed that strain IMMIB L-21 ${ }^{\mathrm{T}}$ was most closely related to species of the genus Nocardiopsis. A tree constructed using the neighbour-joining method, showing the nearest phylogenetic relatives of strain IMMIB L-2 $1^{\mathrm{T}}$, is shown in Fig. 1. The phylogenetic analysis confirmed the placement of strain IMMIB L-21 ${ }^{\mathrm{T}}$ within the genus Nocardiopsis, with the strain forming a monophyletic clade with $N$. composta. However, the association of strain IMMIB L- $21^{\mathrm{T}}$ with $N$. composta was not statistically significant (bootstrap value of $69 \%$ ). Comparative 16S rRNA gene sequence analysis demonstrated that strain IMMIB L-2 $1^{\mathrm{T}}$ displayed sequence similarity values of less than $98.6 \%$ to the type strains of recognized members of the genus Nocardiopsis: highest 


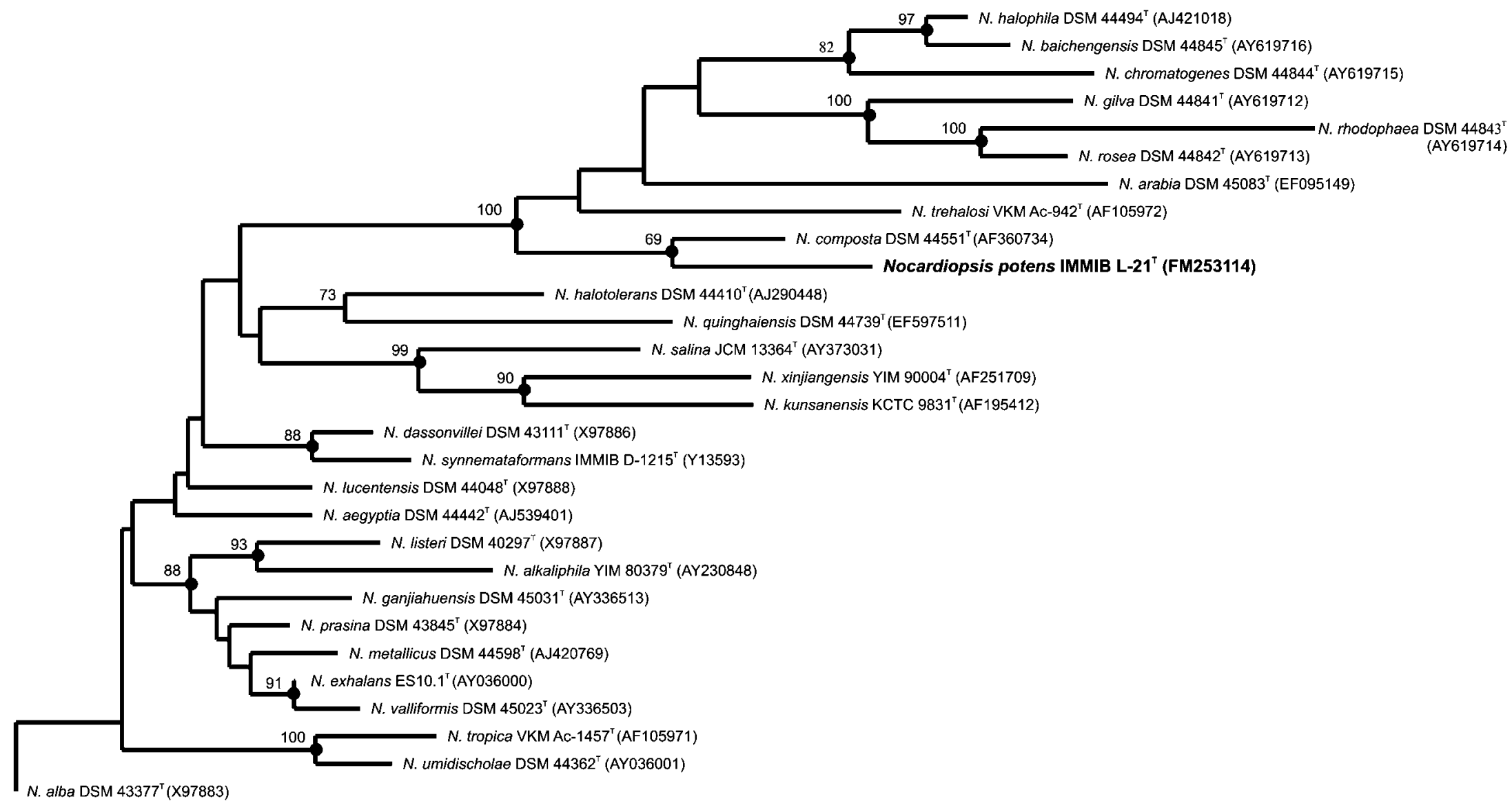

Fig. 1. Neighbour-joining tree showing the position of strain IMMIB L-21 ${ }^{\top}$ in the genus Nocardiopsis. Percentages at nodes ( $\left.>50 \%\right)$ represent levels of bootstrap support based on 500 resamplings. Solid circles indicate that the corresponding nodes were also recovered in maximum-likelihood and maximum-parsimony trees. Nocardiopsis alba DSM $43377^{\top}$ was used as the outgroup. Bar, $5.0 \%$ sequence divergence. 
sequence similarities were shown with $N$. composta DSM $44551^{\mathrm{T}}(98.6 \%)$ and N. halophila DSM $44494^{\mathrm{T}}(98.1 \%)$. However, it is clear from the DNA-DNA relatedness study that strain IMMIB $\mathrm{L}-21^{\mathrm{T}}$ represents a genomic species separate from $N$. composta DSM $44551^{\mathrm{T}}$ (DNA-DNA relatedness value $15.2 \pm 6.08 \%$; mean $\pm \mathrm{SD}$ ) and $N$. halophila DSM $44494^{\mathrm{T}}(6.1 \pm 0.63 \%)$. These values are well below the $70.0 \%$ cut-off point recommended for the assignment of strains to the same genomic species (Wayne et al., 1987). It is also apparent that strain IMMIB L-2 $1^{\mathrm{T}}$ can be distinguished from $N$. composta DSM $44551^{\mathrm{T}}$ and $N$. halophila DSM $44494^{\mathrm{T}}$ by a combination of phenotypic properties (Table 1).

It can be concluded from the genotypic and phenotypic data that strain IMMIB L- $21^{\mathrm{T}}$ is phylogenetically distant from its neighbours and distinguishable from them on the basis of its phenotypic properties. Therefore, strain IMMIB $\mathrm{L}-21^{\mathrm{T}}$ represents a novel species of the genus Nocardiopsis, for which the name Nocardiopsis potens sp. nov. is proposed.

\section{Description of Nocardiopsis potens sp. nov.}

Nocardiopsis potens (po'tens. L. part. adj. potens powerful, pertaining to the metabolic activities of the organism).

Aerobic, Gram-positive, non-acid-alcohol-fast, non-motile actinomycete. Forms a branched substrate mycelium that fragments into coccoid and rod-shaped elements. Aerial hyphae differentiate into straight to flexuous chains of rodshaped spores with smooth surfaces. Pale-yellow to brownyellow substrate mycelium that carries white aerial hyphae is formed on ISP $2-4$. Grows at $20-37{ }^{\circ} \mathrm{C}$, but not at 10 or $42{ }^{\circ} \mathrm{C}$. Diffusible pigments are not produced. Melanoid pigment is not produced on ISP media 6 and 7. Hydrolyses aesculin, casein, elastin, guanine, hypoxanthine, testosterone, tyrosine and urea, but not adenine, gelatin or xanthine. Assimilates acetate, adonitol, adipate, iso-amyl alcohol, L-arabinose, 2,3-butanediol, cellobiose, citrate, meso-erythritol, D-galactose, D-gluconate, D-glucose, myoinositol, L-lactate, lactose, maltose, D-mannitol, melezitose, sucrose and trehalose as carbon sources but not $m$ hydroxybenzoate, p-hydroxybenzoate, 1,2-propanediol, raffinose, L-rhamnose, D-sorbitol or D-xylose. Utilizes Lalanine, arginine, gelatin, proline, ornithine and serine but not acetamide as simultaneous carbon and nitrogen sources. Grows in the presence of $12 \% \mathrm{NaCl}$. Wholeorganism hydrolysates contain meso-diaminopimelic acid and no characteristic sugars. Major phospholipids are diphosphatidylglycerol, phosphatidylcholine, phosphatidylglycerol, phosphatidylinositol, phosphatidylinositol mannosides and phosphatidylmethylethanolamine. Major menaquinones are MK-11 $\left(\mathrm{H}_{8}\right), \mathrm{MK}-11\left(\mathrm{H}_{6}\right), \mathrm{MK}-11\left(\mathrm{H}_{4}\right)$, MK-11 $\left(\mathrm{H}_{2}\right)$, MK-10 $\left(\mathrm{H}_{8}\right)$, MK-10 $\left(\mathrm{H}_{6}\right)$, MK-10 $\left(\mathrm{H}_{4}\right)$, MK$10\left(\mathrm{H}_{2}\right)$, MK-9 $\left(\mathrm{H}_{8}\right)$, MK-9 $\left(\mathrm{H}_{6}\right)$, MK-9 $\left(\mathrm{H}_{4}\right)$ and MK-9 $\left(\mathrm{H}_{2}\right)$. Minor amounts of MK-11, MK-8 $\left(\mathrm{H}_{6}\right)$, MK- $8\left(\mathrm{H}_{4}\right)$ and MK- $8\left(\mathrm{H}_{2}\right)$ are also present. Major fatty acids are anteiso$\mathrm{C}_{15: 0}$, anteiso- $\mathrm{C}_{17: 0}$, iso- $\mathrm{C}_{16: 0}$ and $\mathrm{C}_{16: 0}$. Substantial amounts of iso- $\mathrm{C}_{14: 0}$, iso- $\mathrm{C}_{15: 0}, \mathrm{C}_{17: 1} \omega 8 c, \mathrm{C}_{18: 1} \omega 9 c$, $\mathrm{C}_{18: 0}$ and tuberculostearic acid (10-methyl $\mathrm{C}_{18: 0}$ ) are present.

The type strain is IMMIB L- $21^{\mathrm{T}}\left(=\mathrm{DSM} 45234^{\mathrm{T}}=\right.$ CCUG $56587^{\mathrm{T}}$ ), which was isolated from household waste.

\section{Acknowledgements}

We thank Professor Dr Hans-Georg Trüper for nomenclatural advice.

\section{References}

Becker, B., Lechevalier, M. P., Gordon, R. E. \& Lechevalier, H. A. (1964). Rapid differentiation between Nocardia and Streptomyces by paper chromatography of whole-cell hydrolysates. Appl Microbiol 12, 421-423.

Bernatchez, H. \& Lebreux, E. (1991). Nocardiopsis dassonvillei recovered from a lung biopsy and a possible cause of extrinsic alveolitis. Clin Microbiol Newsl 6, 47-55.

Cashion, P., Holder-Franklin, M. A., McCully, J. \& Franklin, M. (1977). A rapid method for base ratio determination of bacterial DNA. Anal Biochem 81, 461-466.

Collins, M. D., Pirouz, T., Goodfellow, M. \& Minnikin, D. E. (1977). Distribution of menaquinones in actinomycetes and corynebacteria. $J$ Gen Microbiol 100, 221-230.

De Ley, J., Cattoir, H. \& Reynaerts, A. (1970). The quantitative measurement of DNA hybridization from renaturation rates. Eur $J$ Biochem 12, 133-142.

Felsenstein, J. (1981). Evolutionary trees from DNA sequences: a maximum likelihood approach. J Mol Evol 17, 368-376.

Felsenstein, J. (1985). Confidence limits on phylogenies: an approach using the bootstrap. Evolution 39, 783-791.

Fitch, W. M. (1971). Toward defining the course of evolution: minimum change for a specific tree topology. Syst Zool 20, 406-416.

Gordon, R. E. (1966). Some criteria for the recognition of Nocardia madurae (Vincent) Blanchard. J Gen Microbiol 45, 355-364.

Gordon, R. E. (1967). The taxonomy of soil bacteria. In The Ecology of Soil Bacteria, pp. 293-321. Edited by T. R. G. Gray \& B. Parkinson. Liverpool: Liverpool University Press.

Gordon, R. E. \& Mihm, J. M. (1957). A comparative study of some strains received as nocardiae. J Bacteriol 73, 15-27.

Huß, V. A. R., Festl, H. \& Schleifer, K. H. (1983). Studies on the spectrophotometric determination of DNA hybridization from renaturation rates. Syst Appl Microbiol 4, 184-192.

Jukes, T. H. \& Cantor, C. R. (1969). Evolution of protein molecules. In Mammalian Protein Metabolism, pp. 21-132. Edited by H. N. Munro. New York: Academic Press.

Kämpfer, P., Busse, H. \& Rainey, F. A. (2002). Nocardiopsis compostus sp. nov., from the atmosphere of a composting facility. Int J Syst Evol Microbiol 52, 621-627.

Lechevalier, M. P. (1968). Identification of aerobic actinomycetes of clinical importance. J Lab Clin Med 71, 934-944.

Lechevalier, M. P. \& Lechevalier, H. A. (1970). Chemical composition as a criterion in the classification of aerobic actinomycetes. Int J Syst Bacteriol 20, 435-443.

Lechevalier, M. P., De Bièvre, C. \& Lechevalier, H. A. (1977). Chemotaxonomy of aerobic actinomycetes: phospholipid composition. Biochem Syst Ecol 5, 249-260. 
Li, W.-J., Park, D.-J., Tang, S.-K., Wang, D., Lee, J.-C., Xu, L.-H., Kim, C.-J. \& Jiang, C.-L. (2004). Nocardiopsis salina sp. nov., a novel halophilic actinomycete isolated from saline soil in China. Int J Syst Evol Microbiol 54, 1805-1809.

Li, W. J., Kroppenstedt, R. M., Wang, D., Tang, S.-K., Lee, J.-C., Park, D.-J., Kim, C.-J., Xu, L.-H. \& Jiang, C.-L. (2006). Five novel species of the genus Nocardiopsis isolated from hypersaline soils and emended description of Nocardiopsis salina Li et al. 2004. Int J Syst Evol Microbiol 56, 1089-1096.

Ludwig, W., Strunk, O., Westram, R., Richter, L., Meier, H., Yadhukumar, Buchner, A., Lai, T., Steppi, S. \& other authors (2004). ARB: a software environment for sequence data. Nucleic Acids Res 32, 1363-1371.

Meyer, J. (1976). Nocardiopsis, a new genus of the order Actinomycetales. Int J Syst Bacteriol 26, 487-493.

Minnikin, D. E., Hutchinson, I. G., Caldicott, A. B. \& Goodfellow, M. (1980). Thin-layer chromatography of methanolysates of mycolic acid-containing bacteria. J Chromatogr 188, 221-223.

Peltola, J. S. P., Andersson, M. A., Kämpfer, P., Auling, G., Kroppenstedt, R. M., Busse, H.-J., Salkinoja-Salonen, M. S. \& Rainey, F. A. (2001). Isolation of toxigenic Nocardiopsis strains from indoor environments and description of two new Nocardiopsis species, $N$. exhalans sp. nov. and N. umidischolae sp. nov. Appl Environ Microbiol 67, 4293-4304.

Rainey, F. A., Ward-Rainey, N., Kroppenstedt, R. M. \& Stackebrandt, E. (1996). The genus Nocardiopsis represents a phylogenetically coherent taxon and a distinct actinomycete lineage: proposal of Nocardiopsaceae fam. nov. Int J Syst Bacteriol 46, 1088-1092.

Saitou, N. \& Nei, M. (1987). The neighbor-joining method: a new method for reconstructing phylogenetic trees. Mol Biol Evol 4, 406425.

Schippers, A., Bosecker, K., Willscher, S., Spröer, C., Schumann, P. \& Kroppenstedt, R. M. (2002). Nocardiopsis metallicus sp. nov., a metal-leaching actinomycete isolated from an alkaline slag dump. Int J Syst Evol Microbiol 52, 2291-2295.

Shirling, E. B. \& Gottlieb, D. (1966). Methods for characterization of Streptomyces species. Int J Syst Bacteriol 16, 313-340.

Wayne, L. G., Brenner, D. J., Colwell, R. R., Grimont, P. A. D., Kandler, O., Krichevsky, M. I., Moore, L. H., Moore, W. E. C., Murray, R. G. E. \& other authors (1987). International Committee on Systematic Bacteriology. Report of the ad hoc committee on reconciliation of approaches to bacterial systematics. Int J Syst Bacteriol 37, 463-464.

Yassin, A. F. \& Hupfer, H. (2006). Williamsia deligens sp. nov., isolated from human blood. Int J Syst Evol Microbiol 56, 193-197.

Yassin, A. F., Galinski, E. A., Wohlfarth, A., Jahnke, K.-D., Schaal, K. P. \& Trüper, H. G. (1993a). A new actinomycete species, Nocardiopsis lucentensis sp. nov. Int J Syst Bacteriol 43, 266-271.

Yassin, A. F., Haggenei, B., Budzikiewicz, H. \& Schaal, K. P. (1993b). Fatty acid and polar lipid composition of the genus Amycolatopsis: application of fast atom bombardment-mass spectrometry to structure analysis of underivatized phospholipids. Int J Syst Bacteriol 43, 414-420.

Yassin, A. F., Rainey, F. A., Brzezinka, H., Burghardt, J., Lee, H. L. \& Schaal, K. P. (1995). Tsukamurella inchonensis sp. nov. Int J Syst Bacteriol 45, 522-527.

Yassin, A. F., Rainey, F. A., Burghardt, J., Gierth, D., Ungerechts, J., Lux, I., Seifert, P., Bal, C. \& Schaal, K. P. (1997). Description of Nocardiopsis synnemataformans sp. nov., elevation of Nocardiopsis alba subsp. prasina to Nocardiopsis prasina comb. nov., and designation of Nocardiopsis antarctica and Nocardiopsis alborubida as later subjective synonyms of Nocardiopsis dassonvillei. Int J Syst Bacteriol 47, 983-988.

Yassin, A. F., Chen, W.-M., Hupfer, H., Siering, C., Kroppenstedt, R. M., Arun, A. B., Lai, W.-A., Shen, F.-T., Rekha, P. D. \& Young, C. C. (2007). Lysobacter defluvii sp. nov., isolated from municipal solid waste. Int J Syst Evol Microbiol 57, 1131-1136. 